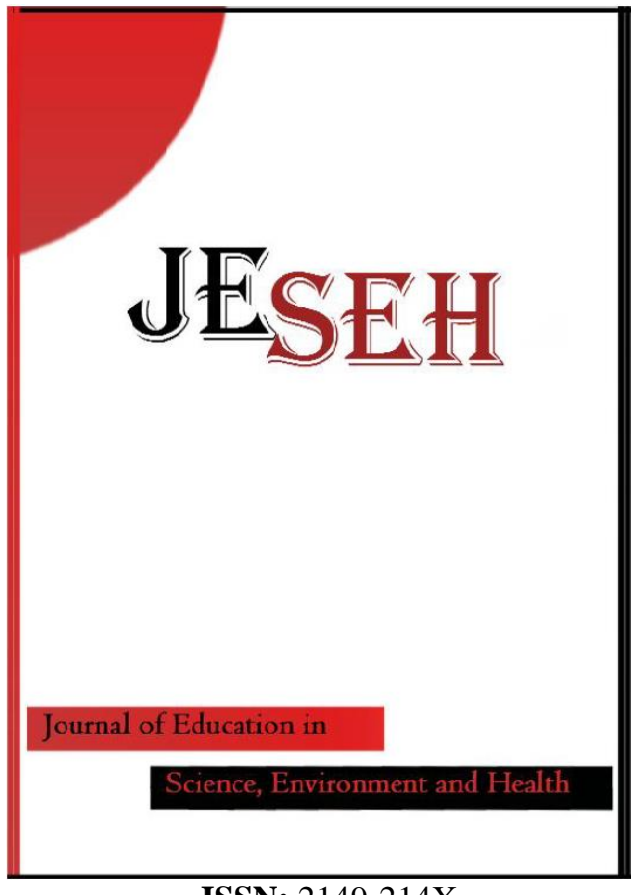

ISSN: $2149-214 \mathrm{X}$

\section{Journal of Education in Science,} Environment and Health

\author{
www.jeseh.net
}

\section{Broad-based Participatory Inquiry into the Definition and Scope of Disaster}

\author{
Fulya Ozturk Tasci ${ }^{1}$, Ayse Oguz Unver $^{2}$ \\ ${ }^{1}$ Privite Turkish School \\ ${ }^{2}$ Mugla Sitki Kocman University
}

To cite this article:

Ozturk Tasci, F. \& Oguz Unver, A. (2017). Broad-based participatory inquiry into the definition and scope of disaster. Journal of Education in Science, Environment and Health (JESEH), 3(2), 165-182. DOI:10.21891/jeseh.326743

This article may be used for research, teaching, and private study purposes.

Any substantial or systematic reproduction, redistribution, reselling, loan, sub-licensing, systematic supply, or distribution in any form to anyone is expressly forbidden.

Authors alone are responsible for the contents of their articles. The journal owns the copyright of the articles.

The publisher shall not be liable for any loss, actions, claims, proceedings, demand, or costs or damages whatsoever or howsoever caused arising directly or indirectly in connection with or arising out of the use of the research material. 


\title{
Broad-based Participatory Inquiry into the Definition and Scope of Disaster
}

\author{
Fulya Ozturk Tasci, Ayse Oguz Unver
}

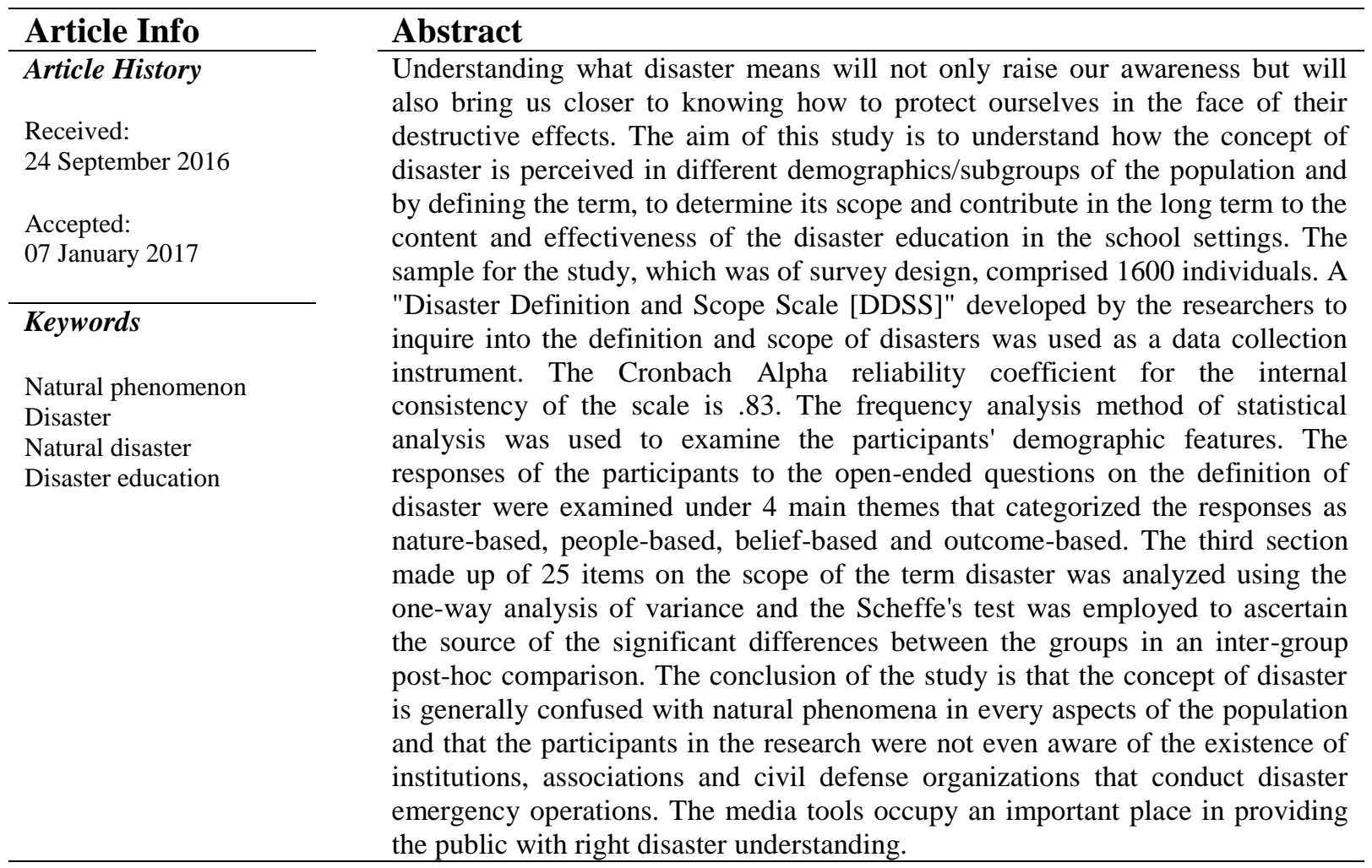

\section{Introduction}

Generally, people have combined their beliefs and curiosity about natural phenomena with science and technology and it is thought that each step that has been taken has brought us closer to the truth. While there is so much knowledge still waiting to be discovered and as the concentration of this knowledge becomes more and more complex with every passing second, people still desires to expand the boundaries of their understanding. Because the reason of the existence of extensive unexplored knowledge in nature has evoked curiosity, and worse, even fear in many people. As questions form in people's minds when science and curiosity join together, it also becomes clearly evident that no scientific facts can differ from person to person or according to different cultures. An example of this is the concept of "disaster." By the same token, the concept of "disaster" should not be different depending upon country or culture. The difference lies in the degree of its impact.

Through the human history, there have been many natural phenomena which have had an impact on the world (e.g., Herodotos, 1, 74; Strabon, 12, 8, 17; Herodotos, 5, 82-85; Strabon, 12, 8, 18; Higgins 2009; Tacitus, Annales, 2, 47; Plinius, Nat. Hist. 2, 200; Ünver, 2012; Şahin, 2012). Natural phenomena have always existed and played a part in people's lives all through history. For tens of thousands of years, countless natural phenomena have occurred in any one year and evidence of these, particularly of earthquakes, has reached us in archeological ruins and in the works of literature that have survived since antiquity. Many accounts of earthquakes, along with related data and narratives (e.g., Capelle, 2006, 62, 81) exist but the description of a tsunami that occurred along the shores of the Mediterranean is a unique account that is of particular significance. In his work, Cassius Dio $(63,26,5)$ relates in the middle of the first century A.D. how giant waves rising from Egypt wreaked havoc over the coast of Lycia. It is without doubt that as a result of the way human beings in antiquity were caught in a perception of the world that stood between myth and religion; many acts of 
nature were thought to be reflections of the wrath of the gods. Hesiod describes how the glorious Zeus could send down punishment so severe that it could demolish an entire city (Hesiod, 239-240) and how earthquakes are created by Poseidon, God of the Seas (Hesiod, 667-668).

The disasters of more recent times that have been imprinted in our memories are the eruption of the volcano Mt. Tambora in Indonesia in 1815, the Texas hurricane of 1900, the San Francisco earthquake of 1906, the earthquake in Chile in 1960, the landslide in Yungay, Peru in 1970, the Kocaeli earthquake of 1999, the floods in Pakistan in 2010, the earthquake and ensuing tsunami in Japan in 2011 (The International Disaster Database [EM-DAT], 2012) and the 2011 Van earthquake (Sever \& Kazancioğlu,2012).

\section{Defining Disaster}

One continues its attempt to assign some kind of meaning to events such as these that create such an impact and cause so much destruction. To define the concept of disaster, the following table has been set up, drawing from definitions of the word by the Turkish Language Association and the terminology of other organizations for which the term is of significance (Table 1).

Table 1. Definitions of disaster

\begin{tabular}{ll}
\hline & The meaning of the word disaster (afet) is described as: a. (n.)1. \\
& Destruction caused by various natural phenomena: That year, the \\
floods were like a disaster. 2. Cataclysm. 3. adj. fig. (figurative) \\
Dire: I now understand how fame can be a dire [disastrous]type of \\
wealth. -R. N. Güntekin 4. Medicine A disorder caused in tissues by \\
Turkish Language \\
Association
\end{tabular}

It can be seen from the table that the definition of disaster varies from organization to organization. In some definitions, disaster is treated as a natural phenomenon. In a study by Cannon (1994), it is stressed that there must be a differentiation made in English between the term hazard, meaning danger or risk, and the term disaster, which pertains to a natural disaster or catastrophe. In the light of this information, then, the definition that has been adopted in this work shall be as described below.

The general term used to describe the consequences of natural or man-made events and/or occurrences that halt or disrupt the normal life functions of communities by causing human beings physical, economic, social, cultural, natural and environmental losses, such that the community affected cannot cope using local resources and interventions." (Kadığlu, 2011).

\section{Studies on Defining Disaster and its Scope in the Fields of Natural Sciences and Medicine and Management}

The negative effects disasters have on the daily lives of individuals have given rise to a need to study why disasters occur. An attempt is being made to explore the reasons for disasters through research in the field of 
natural sciences. It can be seen that these studies are more concentrated in the areas of geology, health sciences, meteorology and engineering.

Related literature in geology reveals that the focus of studies is generally earthquakes (e.g., Arslan, 2003; Ersoy, 2013; Fuse, Igarashi, Tanaka, Kim, Tsujii, Kawai \& Yokota, 2011; Kayrancioğlu, 2007; Uzunçıbuk, 2005; Ünalan, 2010). In natural sciences, studies on disasters appear to be on the scope of disasters, the disasters that have occurred, and the regions that present disaster risk (e.g., Aydın, 2012; Aycan, Toprak, Yüksel, Özer \& Çakır, 2002; Altıntaş, 2005; Uğurlu, Bakım, Güveli, Karamustafalığlu, Soydal \& Ergüder, 2003; Işık, Aydınlıŏ̆lu, Koç, Gündoğdu, Korkmaz \& Ay, 2012).

When studies in the medical field are reviewed, one encounters studies on the psychological trauma in the aftermath of disasters (e.g., Alkan, Elmas, Karakuş \& Akkay, 2001; Nakajima, 2012; Aydın, 2012; Aycan, Toprak, Yüksel, Özer \& Çakır, 2002; Altıntaş, 2005; Uğurlu, Bakım, Güveli, Karamustafalığlu, Soydal \& Ergüder, 2003; Işık, Aydınlıŏ̆lu, Koç, Gündoğdu, Korkmaz \& Ay, 2012). A look into research on disaster management reveals that the subjects treated are preparations for disaster and state of emergency management (e.g., Akdur, 2005; Battal, 2007; Bengtsson et al., 2011; Güler \& Çobanoğlu, 1994; Kadığlu, 2011; Kayrancıŏlu, 2007; Uzunçıbuk, 2005).

In short, although it is apparent that studies on disaster encompass a broad framework in terms of the fields the subject involves, it is also true that apart from the evaluation of the impact of disasters on nature and on living beings, studies on raising awareness about the implications of disaster and on disaster management, there is no reference to other types of research in the literature. Moreover, while there are studies on disasters caused by nature and also mention of natural disasters in the context of preventing disasters, the topics covered are limited to traffic accidents, war, attacks, nuclear power and other activities, and the work of civil organizations. The framework of studying disasters is however quite broad, both in terms of impact and in terms of meaning.

\section{Studies on Defining Disaster and its Scope in the Field of Education}

In the field of education, it can be seen that instead of defining disaster and seeking to create public awareness about its implications, studies focused on outcomes and disasters caused by natural phenomena are in the majority. In this sense, the studies that stand out are on the subject of earthquakes (e.g., Ault,1982; Aydin, 2010; Blake, 2005; Barrow \& Haskins, 1996; Başıüyük, 2004; Dal, 2009; King, 2000; King \& Tarrant, 2013; Leather, 1987; Nakamura, 2007; Öcal, 2005; Öcal, 2010; Ross \& Dargush, 1992; Şimşek, 2007). In a review of these studies, the main research focus is the surveys that were conducted in the elementary and middle schools (e.g., Ault, 1982; Buluş Kırıkkaya, Çakın, İmalı \& Bozkurt, 2011; Buluş Kırıkkaya, Oğuz Ünver \& Çakın, 2011; Fetihi \& Gülay, 2011; King \& Tarrant, 2013; Oğuz, 2005; Özgüven, 2006), in the high schools (e.g., Leather, 1987), the universities (e.g., Barrow \& Haskins, 1996; Dal, 2009; Öcal, 2010) and with adults (e.g., Başbuğ Erkan, Özmen \& Güler, 2011; Başıbüyük, 2004; Buluş Kırıkkaya \& İmalı, 2013; King, 2000; Ross \& Dargush, 1992).

When studies on education related to disasters are examined, it is seen that earthquakes, which are natural phenomena, are directly defined as disasters and most of the studies on this topic have been designed on the basis of this premise. In geology, however, an earthquake is one of the most extraordinary and miraculous natural phenomena, a force that has caused the shaping and formation of the earth and one that is necessary to release the earth's built-up energy. The fact that such a miraculous natural event can be referred to as a disaster is a consequence of the failure to take necessary precautions. It is for this reason that to create awareness about the concept of disaster, the definition of a disaster is necessary and important. In this context, the fact that earthquakes occur through natural processes and their conversion into disasters is a outcome-based result requires defining earthquakes first as natural phenomena. Starting from this point, in the realization that a differentiation between natural phenomena and the concept of disaster is not definitively made in the literature, the related studies in the wide spectrum of different fields has led to certain fundamental conclusions. These conclusions are the following:

1) The research on disasters covers a broad span of different fields of discipline (e.g., geology, medicine, management, education, etc.).

2) When the research is examined, it is seen that most of the studies are on the consequences of disasters and the measures that must be taken.

3) Despite the fact that disaster studies concentrate on a vast outcome-oriented impact, there is limited interdisciplinary research available. 
4) A review of the literature also shows that the studies in the field of education are limited to natural disasters (e.g., earthquakes, floods, landslides, erosion, etc.).

5) The studies in the field of education are more concentrated on a survey type of research and these surveys are generally limited to earthquakes.

6) There is a limited number of studies on defining disaster and creating public awareness.

\section{Purpose of the Research}

The raising of population and the fact that the increasing number of people are distanced from science leads to a substantial lack of awareness in the general public about natural phenomena and as a consequence, to senseless over-growth and development (Kadıoglu, 2007). While this is the case, it is inevitable that most natural phenomena will bring about devastating material and moral damage. Keeping this destruction and loss at a minimum can only be accomplished by becoming acquainted with and understanding nature through a scientific approach to disaster education. Understanding disaster will not only create awareness but will also bring us closer to knowing how to protect ourselves from it.

Becoming aware of what disaster is can therefore only be possible by first defining the term. It is a fact however that the textbooks students follow in the schools that are designed to promote this awareness do not provide a scientific definition of disaster. This is why studies should be produced in this context and disaster education should be based on this basic function. This is how the concept of disaster can be saved from being trivialized to encompass only the concept of earthquakes. The aim of this study from this perspective is to examine how the concept of disaster is perceived in different aspects of the population and by defining the term, to determine its scope and contribute in the long term to the content and effectiveness of the disaster education provided at the schools. In the light of this aim, some of the sub-goals of the study were to develop a scale to measure the knowledge of the various aspects of the population (the middle school students, high school students, university students, and other adult peoples) about disaster as well as their ability to differentiate between disasters and natural phenomena, and in addition, to explore how the different aspects of society define the concept and its scope.

\section{Method}

\section{Research Model and Participants in the Study}

This study was designed within the framework of survey research design. The participants were chosen in terms of convenience sampling that uses participants from target population available at the time and willing to take part (Patton 1987). Furthermore, convenience sampling is used in exploratory research where the researcher is interested in getting an inexpensive approximation of the truth. The reason chosen this method for the current study is that nonprobability method is often used during preliminary research efforts to get a gross estimate of the results, without incurring the cost or time required to select a random sample. Even though it may not provide a representative sample, this is a quick way choosing participants and had general knowledge for further studies.

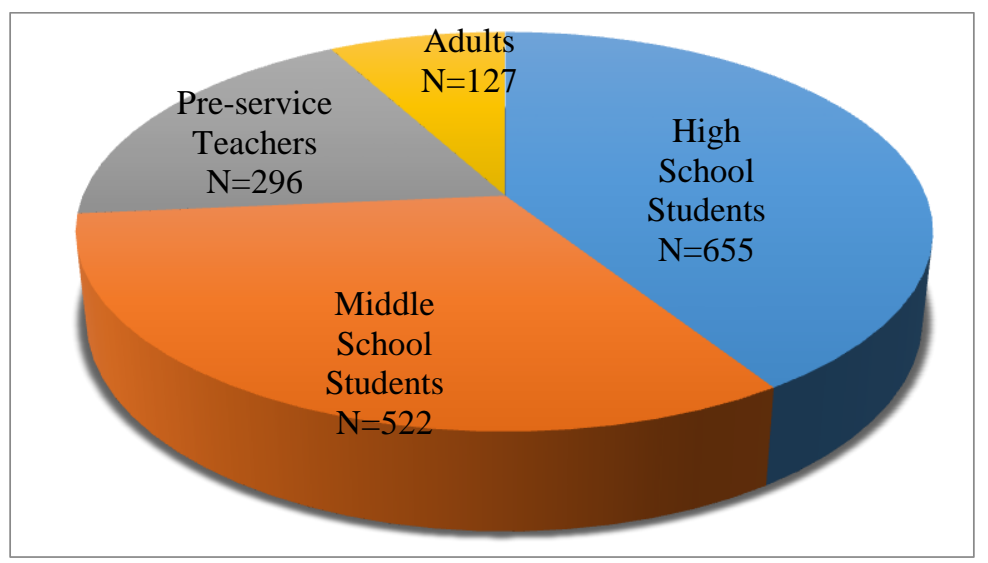

Figure 1.Distribution of participants in research 
The sample for the study comprised 1600 individuals made up of 7 th and 8 th grade (middle school) $(\mathrm{N}=522)$, 11 th and 12th grade (high school) $(\mathrm{N}=655)$, and last-year university students $(\mathrm{N}=296)$, and adults $(\mathrm{N}=127)$ in the metropolitan area of a city in western Turkey. The university participants were last-year pre-service teachers enrolled in the Science Teaching, Social Studies Teaching, Classroom Teaching and Pre-school Teaching Departments. The adults were individuals belonging to different professional groups in the community, having different levels of education. The distribution of the participants in the research is shown in Figure 1.

\section{Data Collection Instrument}

A "Disaster Definition and Scope Scale (DDSS)" developed by the researchers to inquire into the definition and scope of disaster was used as a data collection tool. The scale was developed in three stages.

\section{Stage 1 (A pilot application to analyze related literature and determine student ideas)}

In this first stage, an analysis was made of the course contents and scholastic tests reported in the literature for Science, Life Sciences and Social Sciences Programs and for undergraduates in relevant departments. At the end of the analysis, it was concluded that the concepts of disaster and natural phenomena were not distinctly differentiated from each other. To understand how these concepts were constructed in the minds of the participants, the following open-ended questions were composed:

What is a disaster? Explain.

Is a disaster a natural phenomenon? Explain.

What are some disasters that take place on earth?

The open-ended questions were asked of the 3rd-year students of Elementary School Science Teaching (N: 76), and the participants' views were taken in writing (Oğuz Ünver \& Öztürk 2012). The responses of the participants to each question were gathered together under specific themes. While the participants offered descriptions of the concept of disaster as destruction, loss, earthquakes, death, they described the scope of a disaster as, among others, an earthquake ( $\mathrm{N}: 69)$, floods $(\mathrm{N}: 62)$, avalanches (N: 34), landslides (N: 11), tsunamis (N: 34). To the question, "Is a disaster a natural phenomenon?" $89.47 \%$ of the participants responded as "Yes." The statements in the last section of the tool were formulated in the light of the events and occurrences described as being within the scope of a disaster by the participants in the pilot study and in with the light of the literature. It was decided that all the data obtained from the pilot study would be used in the development of a three-section of the scale that contained demographic questions, open-ended questions and true/false statements.

\section{Stage 2 (Pilot study for developing the scale)}

At the end of the first pilot study in the development of the scale, the DDSS was designed in three sections. The first section covered demographic features; the second section were made up of the two open-ended questions,

What is a disaster? "Explain.

Is a disaster a natural phenomenon? Explain.

The third section was prepared in the form of 25 questions to be answered with the choices of True/False/I don't Know. In order to test the validity of the scale that was drawn up, the views of eight experts, namely four faculty members in the fields of meteorology and disaster management, science education, geography education and linguistics, and four experienced teachers working in public schools. After the experts taken their advices, the scale was revised to its final form. The pilot study was carried out with students at a middle school in a district of western Turkey ( $\mathrm{N}=45)$, 3rd-year students in Science Teaching Department of a public university $(\mathrm{N}=74)$, and adults representing different professions in the community $(\mathrm{N}=11)$, a total of 130 participants.

In line with the results of the pilot study, some revisions were made. To one of the questions about demographics, "What is your profession?" the choice of academic was added to the other choices of teacher, police officer, nurse, lawyer, doctor, and engineer and other. The question, "Have you ever experienced a disaster before?" was removed from the scale because the participants were generally unable to define disaster. To the question, "Is a disaster a natural phenomenon?" the word "only" was added to the statement to make it 
"Is a disaster only a natural phenomenon?" - The final form of the DDSS was reached after the completion of a total of 12 months which included all of the development work and the pilot study.

\section{Stage 3 (Validity and reliability testing of administered scale)}

The internal consistency of the scale was calculated using Cronbach's alpha reliability coefficient and on the basis of the responses given to the 25 three-choice items. The $\alpha$ value calculated was .83 . The scale's Cronbach Alpha $(\alpha)$ values for the different aspects of the community was .83 for middle school respondents, .85 for high school respondents, .81 for university participants and .82 for adults.

Earth science, geologist, and science education specialists were enlisted to establish content validity for the scale. Following this, test templates were prepared to analyze the construct validity of the scale, or the degree to which the test measured what it purported to be measuring. Lastly, the measuring instrument was revised based on the template that was best suited to provide construct validity.

\section{Results}

The research results were analyzed under three headings--demographic characteristics, qualitative and quantitative findings.

\section{Demographic Characteristics of the Participants}

The demographic characteristics of the research sample are presented in the tables below. The frequency analysis method of statistical analysis was used to examine the participants' demographic features in Figure 2.

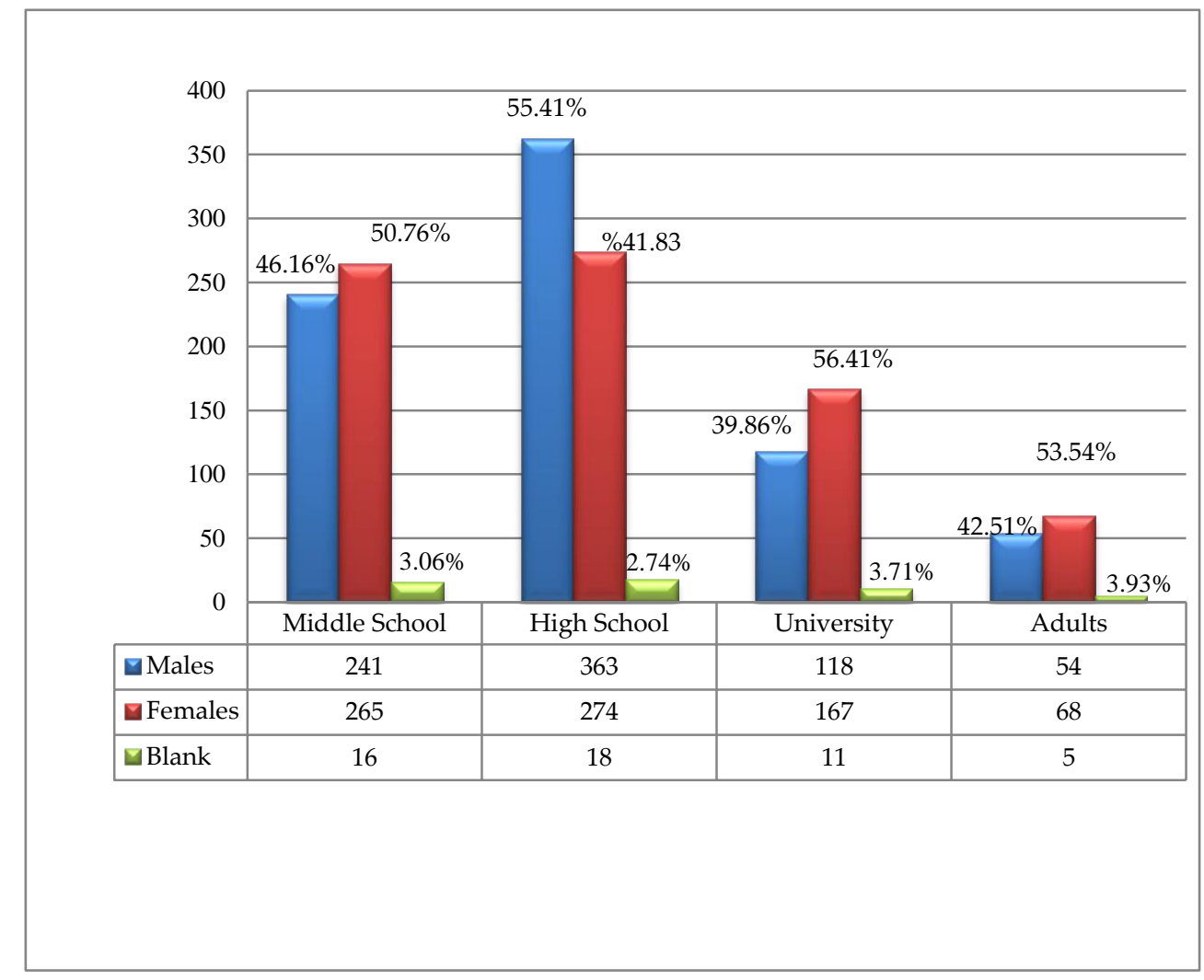

Figure 2. Distribution of research participants by gender

Table 2 shows the kind of schools the students in the research attended and their grades. 
Table 2.Results related to type of school students attended and their grades

\begin{tabular}{|c|c|c|c|c|}
\hline \multicolumn{2}{|c|}{$\begin{array}{l}\text { Types of Schools and } \\
\text { Departments }\end{array}$} & Grades & $\begin{array}{l}\text { Frequency } \\
\text { (f) }\end{array}$ & $\begin{array}{l}\text { Percentage } \\
(\%)\end{array}$ \\
\hline \multirow{2}{*}{\multicolumn{2}{|c|}{ Middle School }} & 7th Year & 283 & 17.68 \\
\hline & & 8th Year & 239 & 14.93 \\
\hline \multirow{5}{*}{ High School } & \multirow{2}{*}{$\begin{array}{l}\text { Vocational } \\
\text { H.S. }\end{array}$} & 11th Year & 60 & 3.75 \\
\hline & & 12th Year & 62 & 3.87 \\
\hline & \multirow{2}{*}{ Anatolian H.S. } & 11th Year & 223 & 13.93 \\
\hline & & 12th Year & 223 & 13.93 \\
\hline & Science H.S. & 11th Year & 87 & 5.43 \\
\hline \multirow{4}{*}{ University } & $\begin{array}{l}\text { Science } \\
\text { Teaching }\end{array}$ & 4th Year & 74 & 4.62 \\
\hline & $\begin{array}{l}\text { Social Studies } \\
\text { Teaching }\end{array}$ & 4th Year & 77 & 4.81 \\
\hline & $\begin{array}{l}\text { Classroom } \\
\text { Teaching }\end{array}$ & 4th Year & 98 & 6.12 \\
\hline & $\begin{array}{l}\text { Pre-School } \\
\text { Teaching }\end{array}$ & 4th Year & 47 & 2.93 \\
\hline
\end{tabular}

Figure 3 displays the educational level, shown in quantitative data, of the adults who comprised a section of the participants.

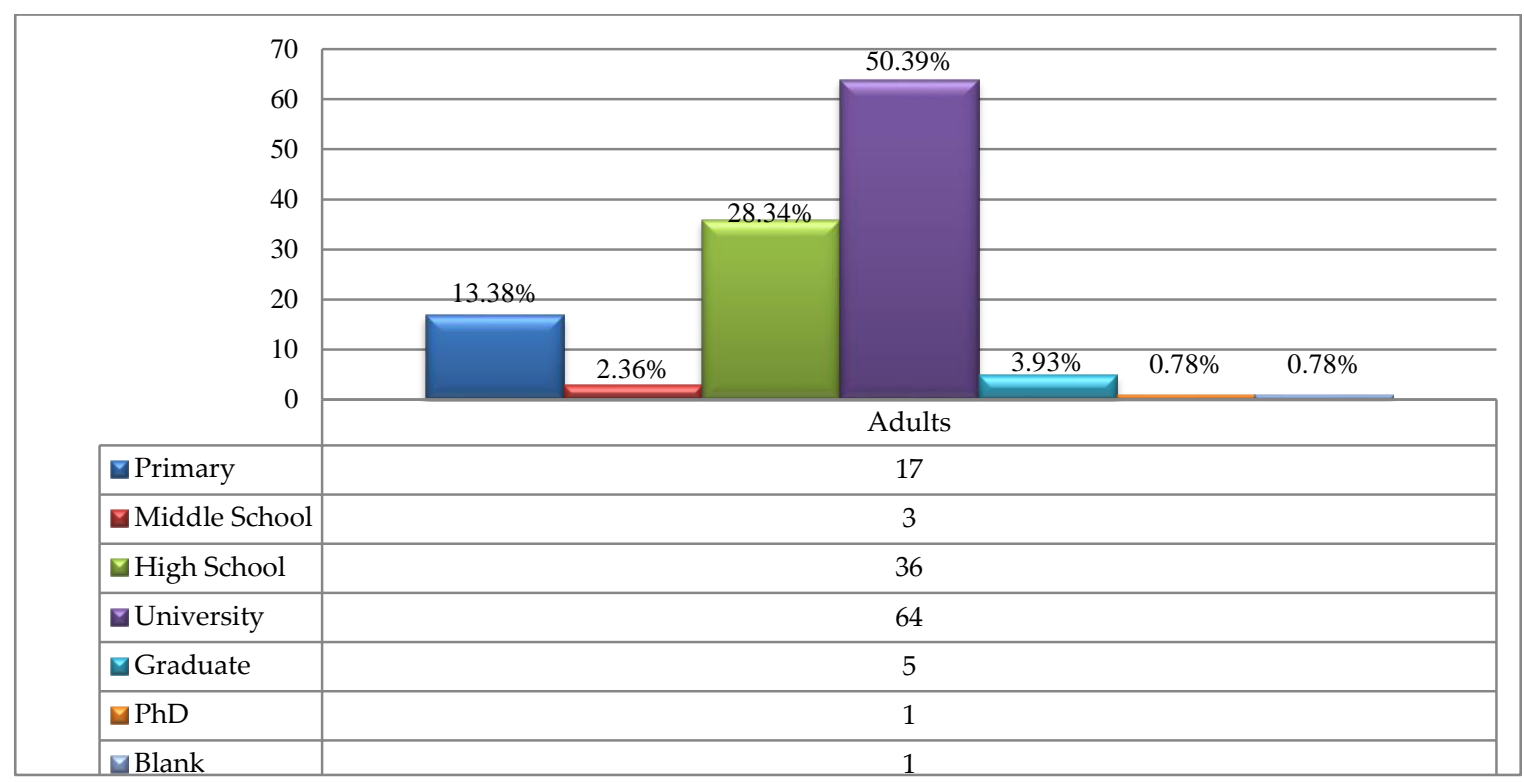

Figure 3. Results related to the educational status of the adults 
The adults were asked, "Do you carry Natural Disaster Insurance (DASK)?" - Of the adults, 59.05\% (N=75) stated that they did not carry DASK even though it was mandatory, and only $39.37 \%(\mathrm{~N}=50)$ revealed that they did. This finding defied the requirement to carry a DASK policy, stipulated by Law No. 4484 dated August 27 , 1999. The question asked of the participants about whether they had attended a disaster training course was answered in the affirmative by 1095 people and negatively by 501. The participants who stated that they had received training were asked what the source was of their training. Their answers are summarized in Figure 4.*

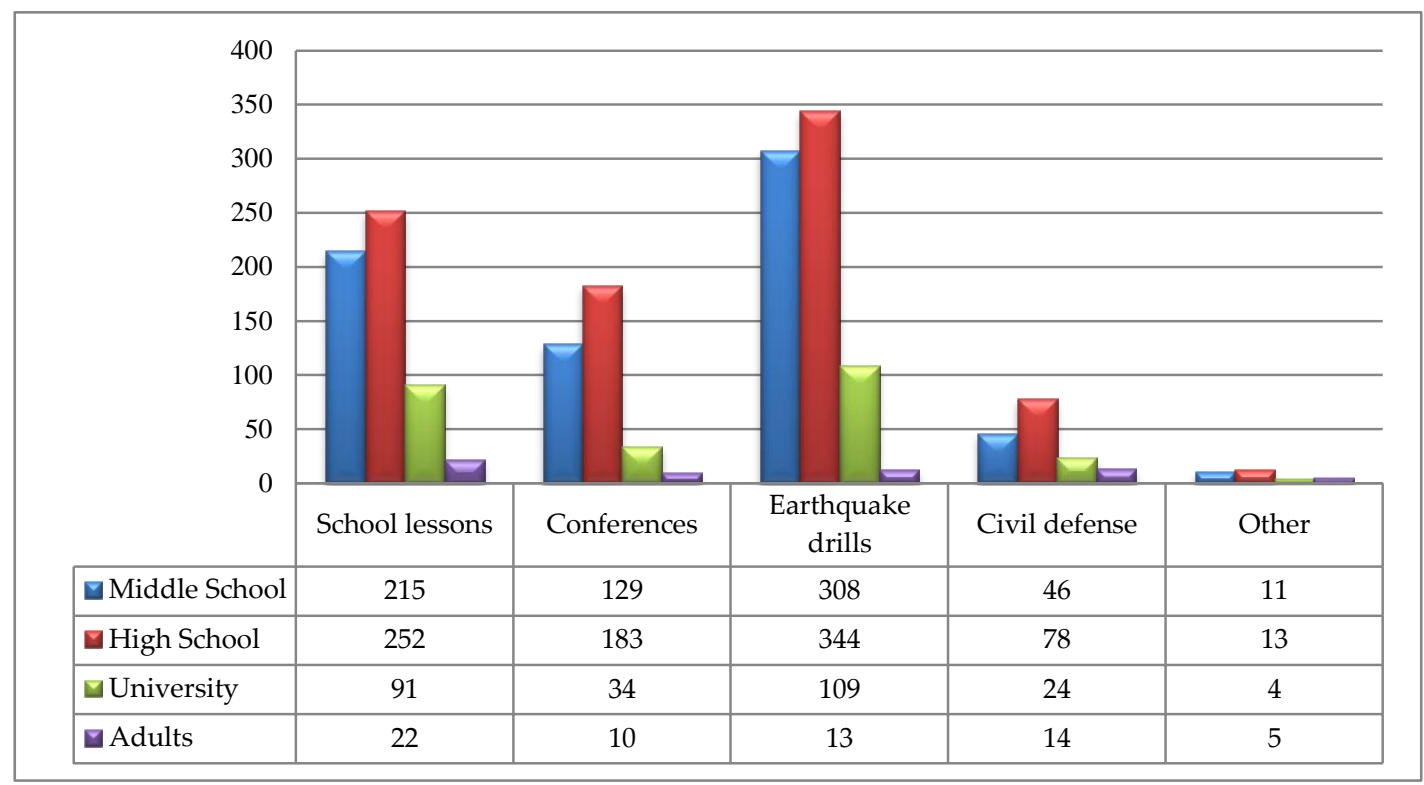

Figure 4. Quantitative data on the sources from which the participants received training Note: Since the participants provided more than one answer to this question, the frequency figures corresponding to the responses should not be compared with the total number in the sample.

A review of the results presented in Figure 4 shows that the training the participants received were earthquake drills and whatever was taught in their classes in school. It can be seen from a more in-depth examination of the data that high school and middle school participants had benefited more from basic training compared to the other respondents. The answers the participants gave to the question, "Are you aware of the work carried out by the Disaster Preparation Unit (AHEB) that was posed to determine the extent of their knowledge about what was being done in the way of disaster preparation are shown in Figure 5.

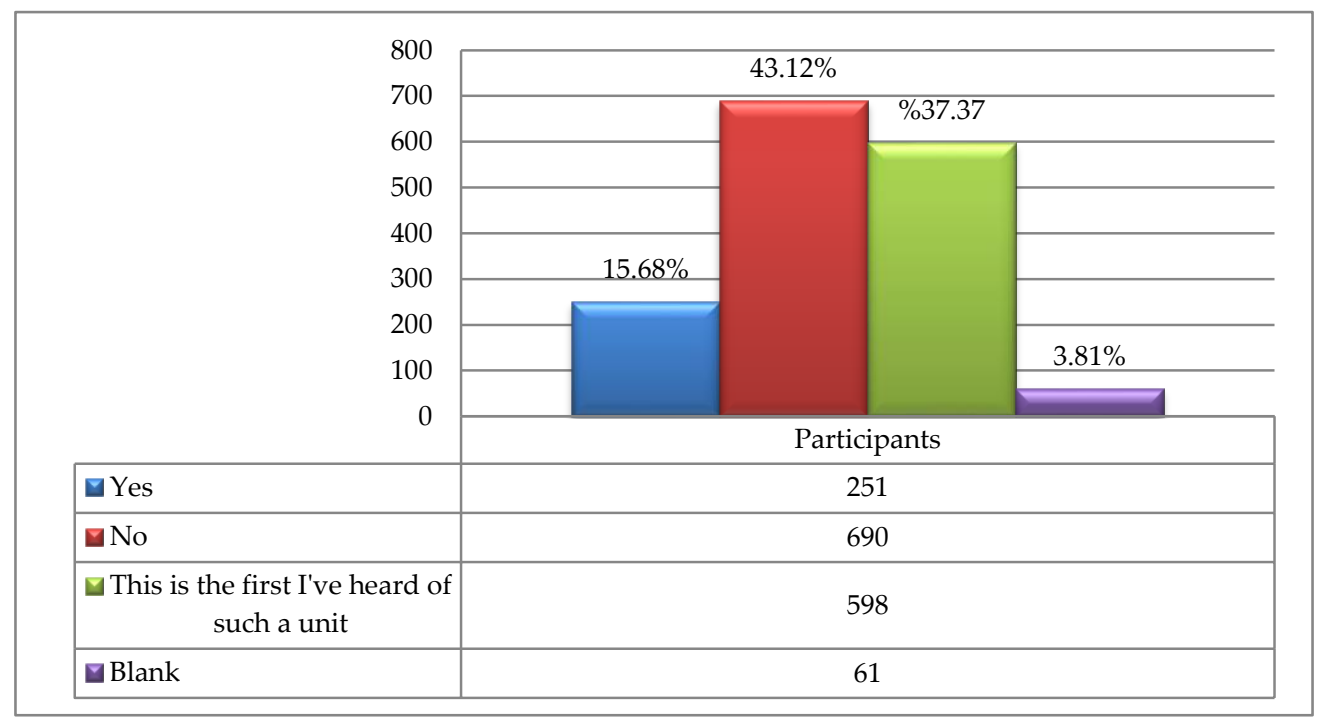

Figure 5. Results related to the awareness of participants about the work of the disaster preparation training unit (DPTU) 
It will be seen in Figure 5, that the level of the participants' knowledge about DPTU is very low. The participants were asked the question "Which sources do you learn from about disasters?" The responses are presented in Figure 6.* The results showed that participants preferred to depend on the daily media sources to get information about disasters.

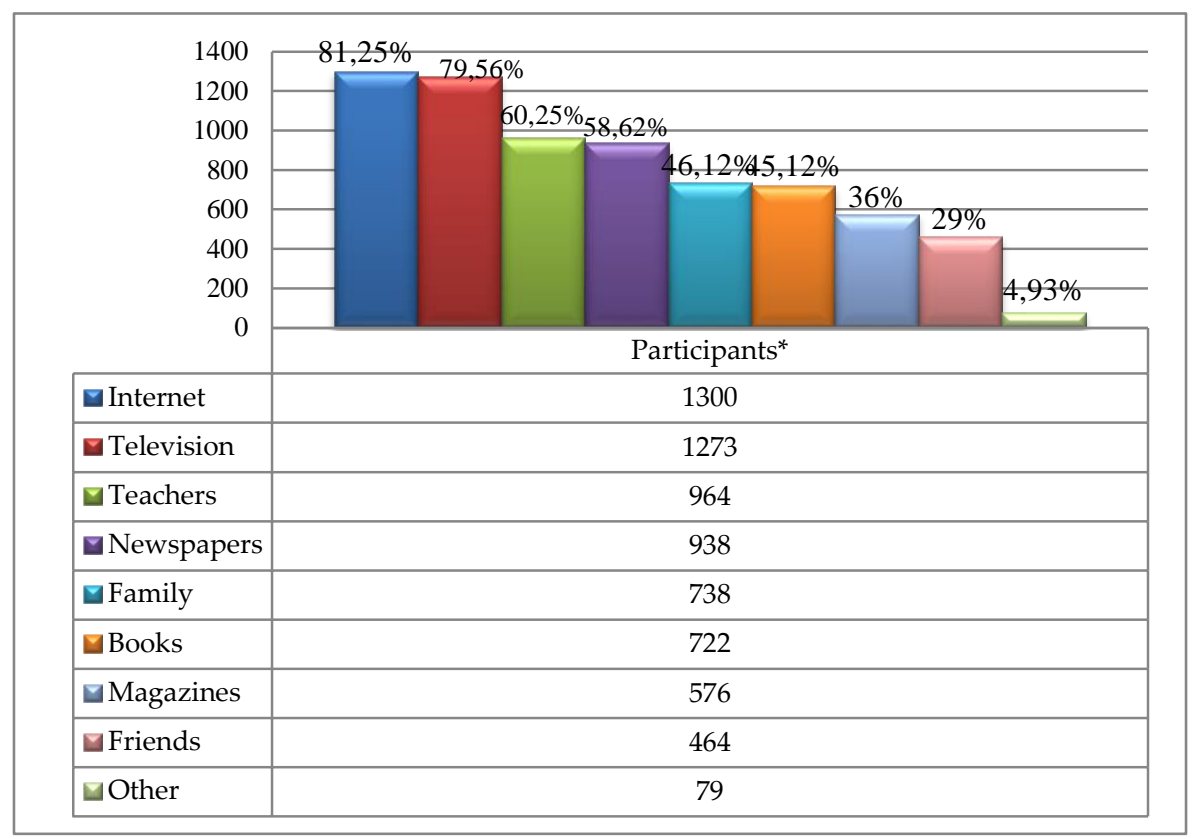

Figure 6. Results related to the sources from which participants obtained information about disasters (Since the participants provided more than one answer to this question, the frequency figures corresponding to the responses should not be compared with the total number in the sample).

\section{Results related to the Definition of Disaster}

In the second section, the question "How would you define disaster?" was asked of the participants. Their responses have been grouped under 4 basic themes. These are the following: Nature-based, People-based, Belief-based and Outcome-based Themes. Examples for each theme are given in Table 3.

Table 3. "What is a disaster?" examples of basic themes in the responses to the open-ended question

\section{Themes}

\begin{tabular}{|c|c|}
\hline Themes & Examples \\
\hline Nature-based & $\begin{array}{l}\text { P1474 (adult group): "A disaster refers to earthquakes, floods, fire, landslides and storms." } \\
\text { P15 (university group): "Disasters are unexpected natural phenomena." } \\
\text { P819 (high school group): "Disasters are various natural events." } \\
\text { P304 (middle school): "A disaster is a natural event that occurs outside man's will." }\end{array}$ \\
\hline People-based & $\begin{array}{l}\text { P51 (university group): "Disasters are temporary and destructive events that occur in the } \\
\text { environment because of the imbalance caused by people who are unaware." }\end{array}$ \\
\hline Belief-based & $\begin{array}{l}\text { P1482 (adult group): "A disaster is an act of God." } \\
\text { P835 (high school group): "Disasters refer to earthquakes, avalanches, landslides, in short, } \\
\text { catastrophe. May God save us all from natural disasters." } \\
\text { P679 (middle school group): "A disaster is dealt out by God..." }\end{array}$ \\
\hline Outcome-based & $\begin{array}{l}\text { P1479 (adult group): "Disasters in their broadest terms are events that cause people loss } \\
\text { and damage." } \\
\text { P829 (high school group): "A disaster refers to the damage sustained by people and the } \\
\text { environment." } \\
\text { P298 (middle school group): "A disaster is an unforeseen, sudden occurrence that results in } \\
\text { vast adversities." }\end{array}$ \\
\hline
\end{tabular}

At the same time, six sub-themes were differentiated under these four basic themes: "Nature and People-based," "Nature and Belief-based," "Nature and Outcome-based," "People and Outcome-based," "Belief and Outcomebased" and "Nature, People and Outcome-based. The responses that were closest to the definition of disaster 
were those categorized under the sub-theme of Nature, People and Outcome-based . Examples for each subtheme are given in Table 4.

Table 4."What is a disaster?" examples of sub-themes in the responses to the open-ended question Themes Examples

P1534 (adult group): "A disaster is a natural phenomenon. It is at the same time an occurrence that stems from people's lack of awareness." P16 (university group): "Disasters can be divided into two groups:

Nature and People-based natural and man-made"

P843 (high school group): "Disasters are things that are caused by people or natural phenomena."

P358 (middle school group): "There are two kinds of disasters: "Natural and Man-made."

P131 (university group): "Disasters are occurrences that are caused by

Nature and Belief-based extraordinary natural events."

P341 (high school group): "A disaster is a natural catastrophe. It is brought about by God."

P1483 (adult group): "Disasters are natural phenomena occurring on the earth such as floods, earthquakes, fires, all of which cause people loss."

Nature and Outcome-based P823 (high school group): "Disasters are natural occurrences that cause losses for man and nature and create material and bodily damage."

P501 (middle school group): "Disasters are natural occurrences unforeseen by man that cause great loss of life and property."

P1483 (adult group): "Disasters are natural phenomena occurring on the earth such as floods, earthquakes, fires, all of which cause people loss."

Nature and Outcome-based P823 (high school group): "Disasters are natural occurrences that cause losses for man and nature and create material and bodily damage."

P501 (middle school group): "Disasters are natural occurrences unforeseen by man that cause great loss of life and property."

P1442 (high school group): "A disaster is an event that happens

People and Outcome-based suddenly and causes people bodily and material harm. In general, it happens because of people."

P939 (high school group): "A disaster is the entirety of events that are Belief and Outcome-based brought to people by God to teach them a lesson and test them in their lifetime, a type of examination when they make mistakes."

P1544 (adult group): "A disaster is the general name given to natural or man-made phenomena that lead to physical, economic and social losses for people, an event that may interrupt or put a stop to people's normal lives and activities and for which resources are inadequate."

Nature, People and Outcome-based P825 (high school group): "Disasters are factors that come about from natural or man-made causes and result in bodily and material loss." P607 (middle school group): "Disasters are events that harm people and are caused by either nature or people."

To ensure the validity and reliability of the analysis, 50 scales were collected from each participating group and analyzed by a second researcher. This was done basically to increase the inter rater reliability of the analysis. To increase consistency, both researchers evaluated each scale individually and made the needed adjustments on the item matrices. After the 50 scales of collected data were encoded, the IRR was calculated on the basis of the matrices rated by each observer.

$$
I R R=\left[\frac{E_{1}-E_{2}}{N}\right] \times 100
$$

$E_{1}=$ Analysis results of first researcher

$E_{2}=$ Analysis results of second researcher

$N=$ Total number of participants

The IRR calculated according to this formula varies between $94 \%-100 \%$ between the items. How the data was collected under the themes described above is shown in Figure 7. 


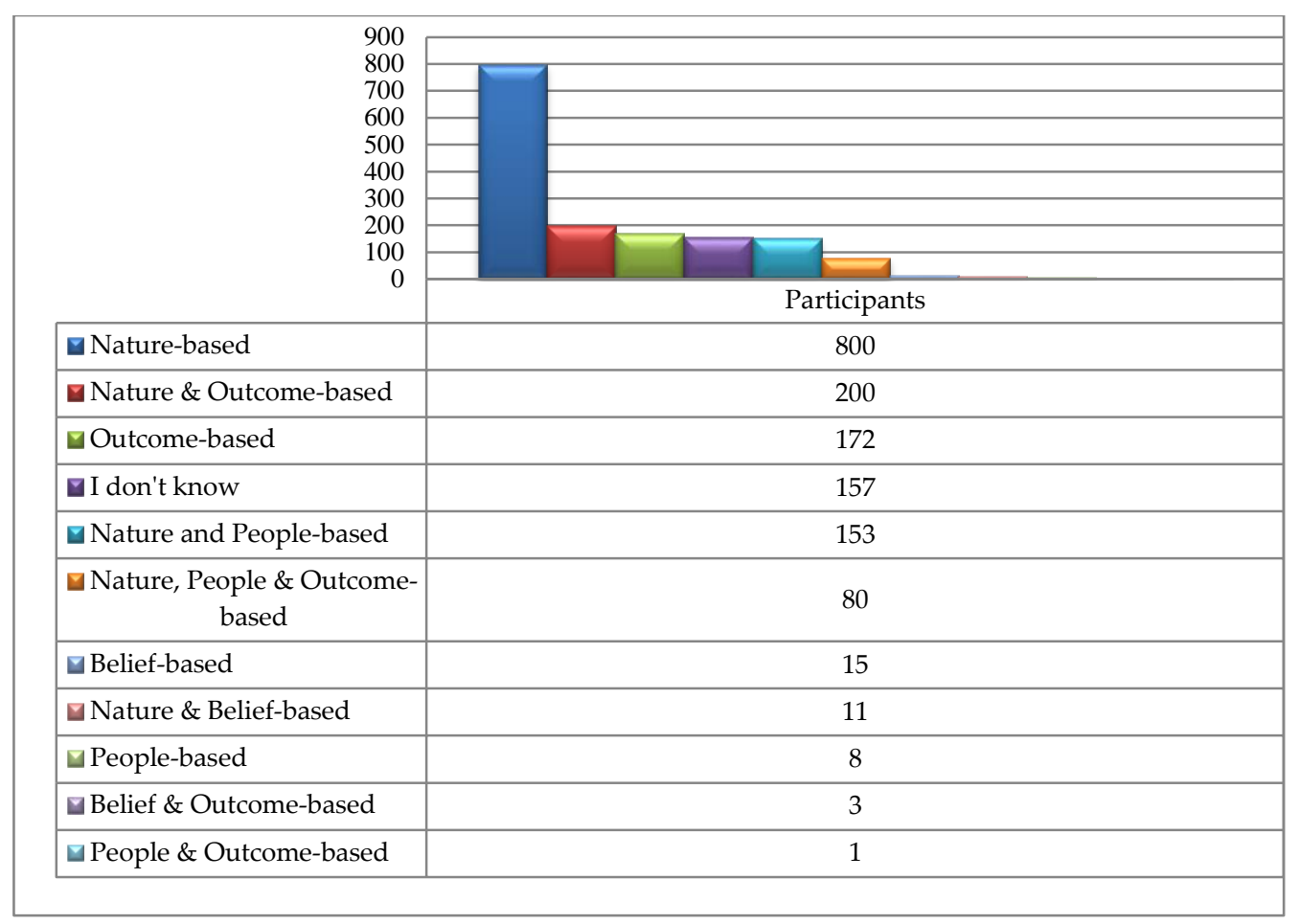

Figure 7. Results related to responses of participants to question "what is a disaster?" by groups

In Figure 7, 49.93\% of the participants $(\mathrm{N}=800)$ describe a disaster as something natural. Of the participants, $0.5 \%(\mathrm{~N}=8)$ think of disaster as people-based, $10.62 \%(\mathrm{~N}=172)$ as outcome-based. It was observed that only $5 \%$ $(\mathrm{N}=80)$ of the participants' responses could be collected under the theme "Nature, People and Outcome-based." An analysis of the definition of disaster by different aspects of the populations is presented in Figure 8.

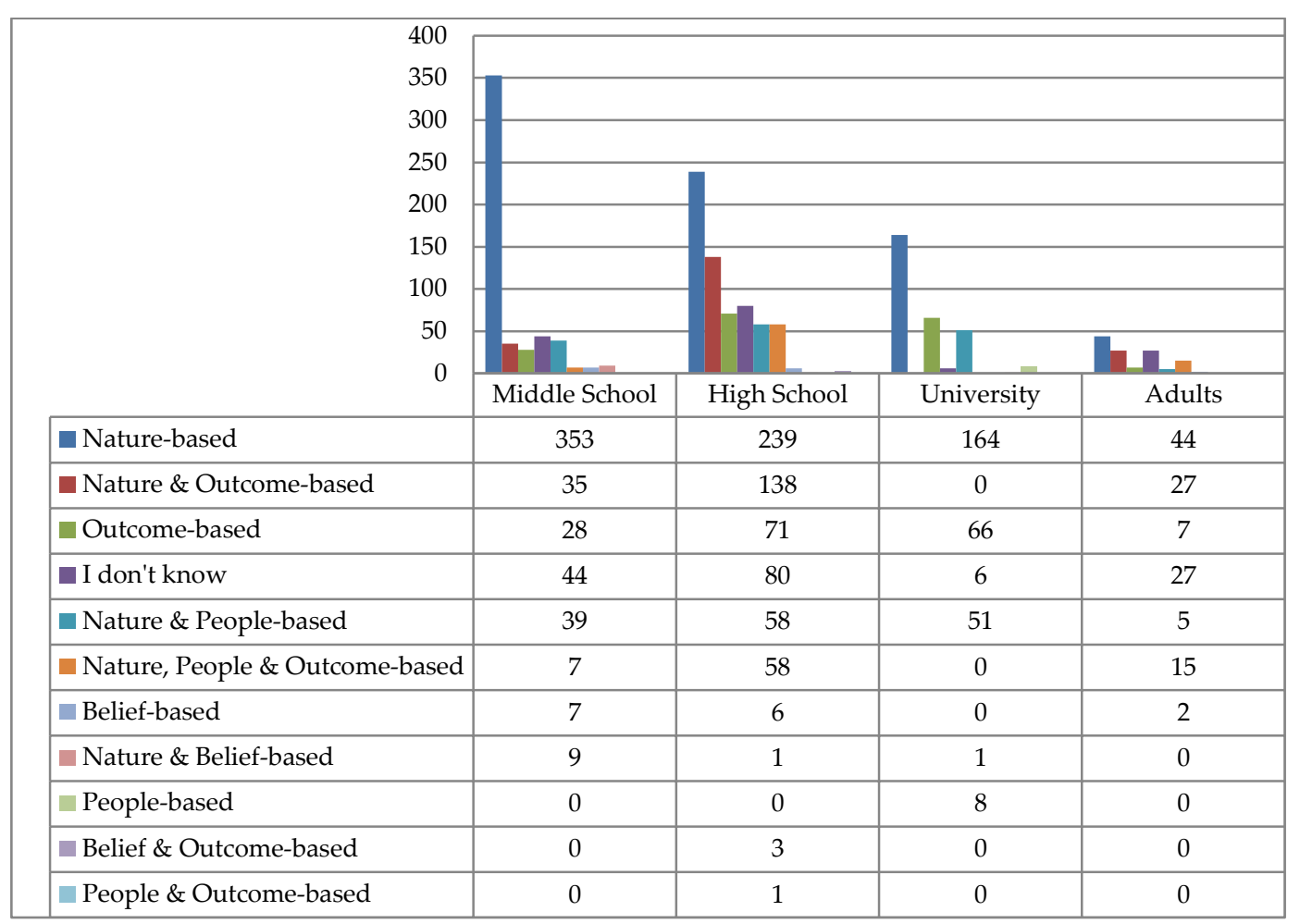

Figure 8. Results related to responses of participants to question "what is a disaster?" by groups

After the written responses of the participants on the definition of disaster were collected, the second question in this section, "Is a disaster only a natural phenomenon?" was asked. The participants were given three choices as 
answers and were asked to mark "Yes," "No," or "I don't know." The responses were coded as Yes: 1, No: 2 I don't know: 0 and a frequency analysis was performed on the SPSS 20 program. The results showed that of the 1600 participants, 78.62\% (N=1258) answered "Yes" while 11.37\% ( $N=182)$ answered "No" and 10\% (N=160) responded "I don't know." The frequency of the answers by participant categories is shown in Figure 9.

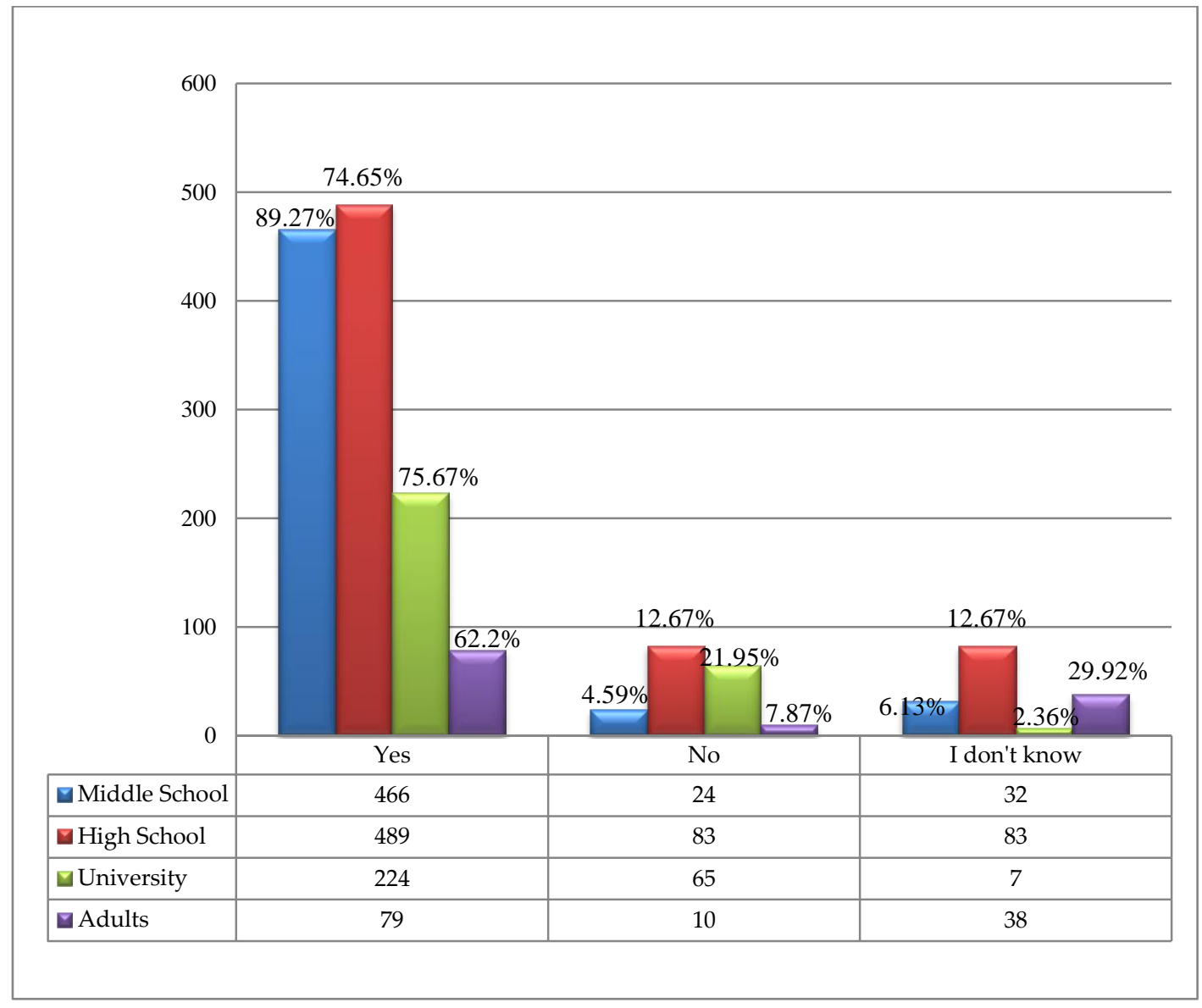

Figure 9. Participants' views on whether a disaster is only a natural phenomenon

\section{Results related to the Participants Views on the Scope of Disaster}

The third and last sections were aimed to determine the knowledge of the participants about the scope of disaster. Here, the participants were asked, "Are the events listed in the table each disasters?" The participants were asked to mark each of the 25 items as Yes/No/I don't know. The responses were coded Yes: 1, No: 2, I don't know: 0 and entered into the SPSS 20 Statistics Program. After the entries were made into the SPSS 20 program, conversions were performed for the items that were considered disaster or only a natural phenomenon.

The conversion of the data led to the categorization of the statements according to the "True" and "False" answers. If in any of the statements, a natural phenomenon was marked by a participant as "Yes" or "I don't know," the participant was scored as having answered incorrectly with a score of (0). If the response was "No," the participant's answer was counted as right and the score was (1). The total score for the third section of 25 items was thus calculated using this scoring system.

The total scores were then analyzed to determine whether there was a significant difference in the level of knowledge about the concept of disaster between the different aspects of the community (middle school, university students and adults). Because the mean scores of more than two groups were to be compared to determine the significant differences between groups, the researchers used the One-way Analysis of Variance (Pallant 2007: 242). Before starting the analysis however, the hypotheses for the data set were tested for verification. The Scheffé's Test, a more cautious method of determining significant differences between groups, was used for a post-hoc comparison to ascertain the direction of the differences. The level of significance for this analysis was found to be $\mathrm{p}<0.05$. The research process is presented in Table 5 . 
Table 5. Results related to the scope of disaster as perceived in the various aspects represented by the participant

\begin{tabular}{|c|c|c|c|c|c|c|c|c|c|c|c|c|c|c|c|c|c|c|c|c|c|c|c|c|}
\hline \multirow{4}{*}{ QUETIOIS } & \multicolumn{24}{|c|}{ PARTCPPAITS } \\
\hline & \multicolumn{6}{|c|}{ Midelle stood } & \multicolumn{6}{|c|}{ Hifigstowl } & \multicolumn{6}{|c|}{ Univeriy } & \multicolumn{6}{|c|}{ Aoblt } \\
\hline & \multicolumn{2}{|c|}{ Yos } & \multicolumn{2}{|c|}{10} & \multicolumn{2}{|c|}{ NA } & \multicolumn{2}{|c|}{ Yes } & \multicolumn{2}{|c|}{ No } & \multicolumn{2}{|c|}{ NA } & \multicolumn{2}{|c|}{ Yes } & \multicolumn{2}{|c|}{ No } & \multicolumn{2}{|c|}{ NA } & \multicolumn{2}{|c|}{ Yes } & \multicolumn{2}{|c|}{10} & \multicolumn{2}{|c|}{ NA } \\
\hline & N & y & N & H & N & x & N & x & N & th & N & x & N & H & N & th & N & H & N & H & N & H & N & th \\
\hline 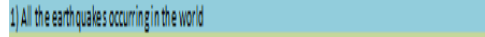 & $4 \pi$ & 9.12 & 26 & i & 20 & 30 & $5 !$ & Q4! & 88 & 127 & "I. & 3.2 & 23 & 84 & 38 & 199 & i & 17 & 10 & $\mathbb{8}$ & 17 & 13.4 & : & 16 \\
\hline 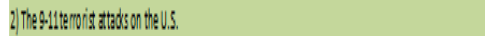 & $b$ & 86 & Q3 & 81 & $\$ 4$ & 103 & 68 & 104 & \$16 & 8.4 & 4. & 6.3 & \%. & 24 & 24 & 689 & 2. & 7,1 & 2 & 10,3 & 10 & 787 & i & 39 \\
\hline 3) Trificardent withist ites & 8 & 1.13 & 38 & 839 & 25 & 48 & 57 & 87 & 573 & 87,5 & 25 & 38 & की & 26 & 28 & 736 & 14 & 47 & 2 & 16,5 & 97 & 764 & 9 & 7,1 \\
\hline 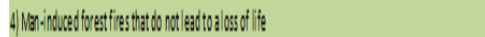 & 28 & $50 \mathrm{~A}$ & 25 & 4.2. & 4 & 80 & 23 & 47 & 317 & 484 & 45 & 69 & 15 & 5.7 & 117 & 395 & 14 & 47 & 8 & 37 & $\pi$ & 367. & 8 & 63 \\
\hline 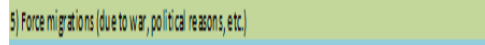 & \$ل & 10,3 & 42 & $\pi$ & 66 & 26 & 66 & 10.1 & 335 & 819 & $\$ 4$ & 8.8 & y & 49 & 211 & 71,3 & 29 & is & 17 & 3,4 & 102 & 003 & 8 & 63 \\
\hline 6) Sobrecipes & 1.80 & 36 & 215 & 459 & $\theta$ & 17 & 173 & 26,4 & 4.15 & 6.4 & 67 & 10,2 & 74 & 8 & 98 & 699 & 24 & 81. & 33 & $z$ & 87 & 685 & 1 & 5.5 \\
\hline 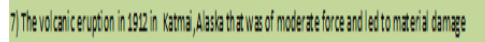 & 48 & $\pi 72$ & \& & 1.23 & 55 & 10,5 & 96 & 895 & 38 & 98 & 31 & 47 & 254 & $\$ 2$ & 24 & 8.1 & 8 & 27 & 14. & 98 & 10 & 79 & 3 & 24 \\
\hline 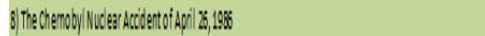 & $\$$ & 18 & 48 & 69.7 & 80 & 193 & 104 & 266 & 433 & 66. & 48 & 1,3 & 132 & 4,6 & 152 & 5.4 & 12 & 41. & 4 & 2,6 & 74 & 583 & 9 & 7,1 \\
\hline 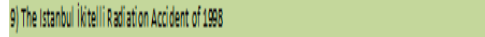 & 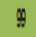 & 19 & 将 & 64. & 78 & 49 & Wh & 237 & 4! & 67,3 & 65 & 99 & 110 & 37,2 & 159 & 387 & 27 & 91 & 37 & Q1.1 & $\pi$ & 60,5 & 13 & 10.2 \\
\hline 10k kidrin & 32 & 636 & 21 & 33.2 & 69 & 13.2 & 42 & 70,5 & 142 & 417 & 31 & 7,8 & 265 & 斗 3 & 61 & 206 & 30 & 10.1 & 2 & 197 & 25 & 724 & 10 & 7,9 \\
\hline 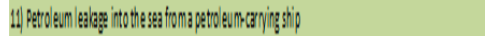 & 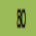 & 15,3 & \$9 & 745 & 3 & 102 & 108 & 165 & 497 & 798 & 50 & 7,6 & $\$$ & 87) & 182. & 6.5 & 29 & 98 & 3 & 27,6 & $\infty$ & 63 & 12 & 9,4 \\
\hline 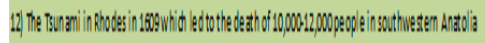 & 48 & 86 & 37 & 7,1, & 36 & 69 & 93 & 46 & 32 & m, & 30 & 49 & 28 & 89 & 13 & 4 & s & 17 & 12 & 8,3 & ? & 16 & 4 & 31. \\
\hline 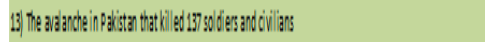 & 46 & 854 & 13 & 8.2 & 33 & 6,3 & 616 & $\$ 4$ & 10 & 1.5 & 29 & 44 & $2 \pi$ & \$, 3 & it & 47 & 3 & 1 & 12 & 8,1 & : & 1.6 & 3 & 24 \\
\hline 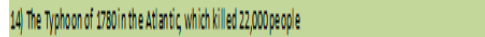 & 3 & 76. & 48 & \$4 & 74 & 42 & 59 & $m$ & 29 & 44 & 37 & 5.6 & 28 & 56 & 11 & 37,7 & ? & Q7 & 12 & 5,3 & ? & 16 & 4 & 3.1 \\
\hline 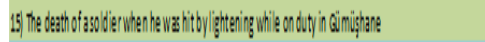 & 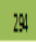 & 36,3 & 169 & 324 & 59 & 113 & Q33 & 646 & 166 & 253 & 66 & 10,1 & 197 & 46 & 76 & 257 & 23 & 7,8 & 8 & 8, ? & 31 & 24 & 10 & 7,9 \\
\hline 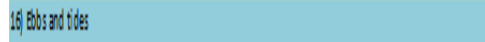 & 297 & 369 & 45 & 278 & 80 & 193 & 283 & 43.2 & 317 & 484 & 35 & 84 & 14 & 8,5 & 157 & 33 & 25 & 84 & 6) & $\$$ & 59 & 465 & 1 & 5.5 \\
\hline 17) Lrstelip: & 18 & 336 & 27 & 4,3 & M & 17 & 16 & 299 & 402 & 6,4 & 57 & 87 & ก. & a & 21 & 679 & 24 & 81 & 2 & 189 & 9 & 764 & 6 & 47 \\
\hline $180 \mathrm{pogeth}$ & $2 \pi$ & 52.1 & 180 & 3.45 & 70 & 34 & 39 & 699 & 20 & 30,8 & $\$ 4$ & 8.2 & 20 & 4,3 & 60 & 20,3 & 16 & 5.4 & 8 & $\pi, 2$ & 19 & 15 & 10 & 1,9 \\
\hline 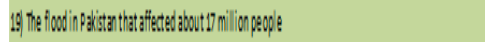 & 458 & 87,4 & 35 & 67) & 31 & ig & 677 & 2:27 & 23 & 3.5 & 15 & 38 & 20 & \$, 6 & 13 & 4 & 3 & 1 & 18 & 8,9 & ? & 16 & ? & 1,6 \\
\hline 201ansidide & 40 & 9 & 21 & 4 & 2. & 4 & 60. & 9,8 & 31 & 47 & 23 & 3.5 & 261 & 82 & 29 & 98 & 6 & ? & 1.18 & 29 & 8 & 6.3 & 1 & 0.8 \\
\hline 2) |amsip & 480 & 898 & 28 & 5.4 & 25 & 48 & 60 & 83.1 & 23 & 3.5 & \# & 3.4 & 28 & 8,5 & 30 & 101 & 7 & 24 & 116 & 9,3 & 10 & 79 & $!$ & as \\
\hline 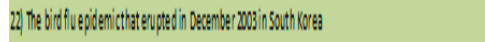 & $\pi$ & 144 & 30 & 728 & 67 & 28 & 48 & 226 & 4,4 & 6.63 & 73 & 41.1 & 108 & is & 155 & 524 & 38 & 128 & $y$ & $\$, 7$ & 69 & 5,13 & 19 & 15 \\
\hline 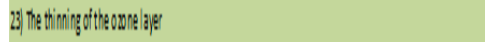 & 26 & $4,3,3$ & 23 & 4,8 & 83 & 59 & 265 & 37,6 & 366 & 498 & 83 & 12,7 & 129 & $B, 6$ & 12. & 4.2 & 45 & 15.2 & 3 & 4,3 & 55 & 43,3 & 17 & $1: 34$ \\
\hline 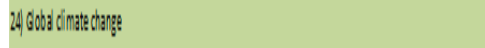 & 25 & 485:5 & $\mathbb{M}$ & 391 & 65 & 2.5 & 27 & 426 & 30 & 4.88 & 76 & 116 & 13 & 4.6 & 117 & 395 & 4 & 49 & 5 & 43.3 & 36 & 4.1 & 16 & 126 \\
\hline 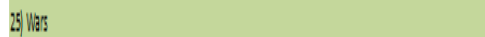 & 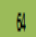 & 123 & 49 & M.,3 & 39 & 7,5 & 97 & 488 & 510 & 779 & 48 & 7,3 & $\pi$ & ast & 24 & 679 & 17 & ;) & 15 & 48 & 105 & 827 & , & 5.5 \\
\hline
\end{tabular}

A participant can score a minimum of 0 and a maximum of 25 on the Definition and Scope of Disaster Scale (DSDS) that is used to determine the level of knowledge about the concept of disaster. The number of participants $(\mathrm{N})$, mean scores $(\overline{\mathrm{X}})$, and standard deviations (SD) (of the middle school, high school, university students, and other adults) are presented in Table 6.

Table 6. The central tendency and distribution values for the scores of the middle school, high school, university students and adults on the dsds

\begin{tabular}{lccc}
\hline Participating groups & $\mathrm{N}$ & $\overline{\mathrm{X}}$ & SD \\
\hline Middle School Students & 522 & 11,44 & 3,29 \\
\hline High School Students & 655 & 12,80 & 3,70 \\
\hline University Students & 296 & 14,42 & 3,94 \\
\hline Adults & 127 & 13,84 & 3,80 \\
\hline
\end{tabular}

One-way analysis of variance was used to determine whether there was a significant difference in the level of knowledge of the different aspects of the community indicated in Table 6 (middle School, high school and university students and adults) about the concept of disaster. The results of the analysis can be found in Table 7.

Table 7. Results of the one-way analysis of variance (ANOVA) on the knowledge levels of middle school, high school, university students and adults about the concept of disaster

\begin{tabular}{ccccccc}
\hline $\begin{array}{c}\text { Source of } \\
\text { Variance }\end{array}$ & $\begin{array}{c}\text { Sum of } \\
\text { Squares }\end{array}$ & $S D$ & $\begin{array}{c}\text { Squares } \\
\text { Mean }\end{array}$ & $F$ & $p$ & $\begin{array}{c}\text { Level of } \\
\text { Significance }\end{array}$ \\
\hline Inter group & 1868,50 & 3 & 622,83 & 47,25 & .000 & Yes \\
\hline Intragroup & 21036,43 & 1596 & 13,18 & & & \\
\hline Total & 22904,93 & 1599 & & & \\
\hline
\end{tabular}


According to Table 7, a statistically significant difference was found between groups $\left(F_{(3,1529)}=47,25, \mathrm{p}=.00\right)$. A post-hoc comparison was performed with Scheffé's Test to account for multiple comparisons between group, While the test results showed significant differences between the university students $(\mathrm{M}=14.42, \mathrm{Sd}=3.94)$ and the high school students $(M=12,80, S D: 3,70)$ and middle school students $(M=11,44, S D=3,29)$, no statistically significant difference was observed between the university students and the adults $(\mathrm{M}=13,84, \mathrm{SD}=3,80)$. This shows us that parallel to the increased education that the middle school, high school and university students received, there was also a significant improvement in their knowledge about the concept of disaster, but that the university-level participants and the adults did not demonstrate any improvement in the level of their knowledge about the concept.

\section{Discussion, Conclusion and Recommendations}

Every person has his or her own perception of how to define disaster. The most common perception exhibits the confusion between a disaster and a natural phenomenon (78.62\%). Just as every natural phenomenon is not a disaster, every disaster does not stem from nature. As long as the knowledge of the general public about what disaster is buried in the murky waters of what has customarily been taught about disasters, everyone will continue to believe that a disaster is an act of nature and that it cannot be prevented. Although there are limited references to this matter in the literature, what little there is supports our argument (Buluş-Kırıkkaya et al., 2011; Cannon, 1994). Indeed, Kadığlu (2011) has called attention to disasters within a broad scope of the term, pointing to natural, man-made and technology-based disasters and has discussed the need for separate emergency plans for each type of disaster.

The present study has shown that the participants' knowledge of disasters is largely based on earthquake drills and classroom lessons. Parallel to this, a review of the sources of knowledge that the participants have benefited from with regard to learning about disasters points to the internet and television. We can therefore say that these two channels of communication are effective tools in raising awareness in the public about disasters. Another researcher, Coşkun (2011), has examined in a section of a study the association found between age and the devices owned and used at home and asserted that individuals in the 21-40 age groups are more efficient users of television and the internet compared to users at other ages. The same study also shows that disaster education programs should follow a systematic, regular and renewable process. Öcal (2010) reached the conclusion in a study examining the level of knowledge of primary school pre-service teachers about earthquakes that the participants confused the "size" with the "magnitude" of an earthquake and that this confusion was caused by the explanations of authorized and unauthorized persons over the media channels. Another researcher, Koç (2013), concluded that the most common sources of news about natural disasters were about earthquakes and that these were generally magazine-style human interest stories. Other outcomes of the research were that natural disasters maintained their place in the public interest for as long as they had an impact on social, economic and daily life but when their current relevance faded, they were no longer made the subject of news in the press. Similarly, Barrow \& Haskins (1996), in their study with 186 geology students, reported that participants could not define an earthquake and that their knowledge about earthquakes came from TV news stories, newspapers and films.

Our findings about the Disaster Preparation Education Unit (DPEU) showed us that the study subjects were not very informed about the existence of this organization. Varol (2007) also in the study entitled, "Raising Public Awareness about Natural and Technological Disasters and the Role of AFEM" noted that although AFEM (European Natural Disasters Training Center), established as a result of the European and Mediterranean Major Hazards Agreement (EUR-OPA), targeted experts, administrators, educators, decision-makers, primary schools and the general public in its programs of education, most of the aspects of the population were not aware of the existence of AFEM. This finding is true despite the fact that the primary aim of the European Natural Disasters Training Center (AFEM) is to gradually educate the public, and instigate disaster-awareness. A study by Coşkun (2011) queried the impact of the work carried out by the Disaster Preparation and Earthquake Training Association (AHDER), an organization that started to work in various ways in cooperation with different intervention and assistance associations in the provinces and districts after the 1999 Marmara Earthquake. The investigation revealed that the public was not knowledgeable about what to do before or after an earthquake and that although people felt the need for training in the face of the destructive effects that they experienced during the earthquake, the training they in fact received was focused not on pre-earthquake training but on what to do in the aftermath of an earthquake. It is however just as important and necessary to execute interventions before a disaster strikes than it is to execute them afterward. 
It was seen in the present study that the middle school participants were more likely to associate the concept of disaster with earthquakes. The focus on the idea of an earthquake perhaps may be due to the extended emphasis of the media in Turkey on the natural phenomenon of earthquakes. Another reason might be that the area in which the study was conducted is geographically and geologically classified as a first degree earthquake hazard area. Besides this, because almost every natural disaster brings out dire consequences, differentiating between the concept of a natural phenomenon and disaster becomes difficult. This might be why people generally refer to an explosion or an accident as a catastrophe but speak about the adverse results of natural phenomena as natural disasters.

When the adage, "Schooling begins at home," is considered, it becomes clear that the findings of this study point to the reality that while children should be educated and their awareness raised about disasters, families also need to be included in the education cycle. In this context, the fact that the percentage of participants receiving disaster education dropped the higher their level of education brings to mind two reasons for this. The first of these is that, related to the great loss the country has suffered due to disasters, the reforms made in education have increased the importance of disaster education and therefore middle school students have started to benefit from these progressive efforts, albeit not adequately. A second reason may stem from the fact that disaster training provided in childhood years may not be easily integrated into practical life in adulthood and that knowledge presented theoretically may be considered to not have been taught at all, remaining only as an abstract classroom concept.

It can be seen that studies on disasters have been conducted in a broad scope of different areas and this might have been because the losses that were sustained have been considered in the context of various categories (e.g., architecture, health, education, management). Deficiencies in any one of these areas that result in disaster may bring out different dimensions. In this, it must not be forgotten that remedying the deficiencies present in any of these areas is a process that must go hand in hand with providing education.

Presenting systematic and regular information to the public about disasters and natural phenomena will increase the confidence individuals have in their own knowledge. As people's confidence about their own knowledge increases, they will be more open to learning and as they learn more, they will become aware that the knowledge they possess is of lifesaving significance. Achieving sustainable disaster education is dependent upon defining the concept of disaster in absolute, simple and clear terms. It can only be after this is done that natural events will cease to be objects of fear and awareness about the preventability of disasters can flourish and be rescued from the bonds of a fatalistic outlook.

The general conclusions the study reached are summarized below.

1) The concept of "disaster" is confused in all aspects of the population with natural phenomena and this results in the use of the term "natural disaster."

2) The different aspects of the population are not aware of the existence of institutions, associations and nongovernmental organizations that work in the area of disaster control.

3) The media occupies an important place in terms of providing the public with information about disasters. The information learned from media sources are more effective sources of knowledge than other sources of information.

4) While the maximum possible score on the DDSS is 25 , the average scores received by the different participants ranged between 11.44-14.42. This indicates to us that the concept of disaster is not fully understood and events that lie in the scope of disaster are misinterpreted.

5) The work carried out to create public awareness about the definition and scope of the concept of disaster is quite limited.

Many disasters have taken place around the world during the course of the present study. These disasters were without doubt either preventable or the scope of their destruction could have been reduced. One such disaster that took its toll in Turkey was the recent Soma mining disaster in which 301 miners lost their lives. As with prior disasters, it is clear that this mining disaster too was the product of neglected precautions and inadequate auditing and inspections. As with the 1999 Marmara Earthquake, where 17,480 souls perished, the devastation caused will not by itself be enough to prevent such disasters from happening again and the many lives lost will continue to be the price that humanity will have to pay. If measures had been taken or if the precautions that were put into place had been adequate, this loss of lives and property would not have occurred and the 
destruction would have been less overwhelming. Indeed, disasters such as these not only result in the loss of lives and property, they also wreak havoc over the psychological state of society as a whole.

Understanding what disaster means will not only create our awareness but will also bring us closer to knowing how to protect ourselves in the face of this adversity. Creating awareness about disaster is therefore only possible by first defining the term. Being aware is to take on responsibility. If awareness can be created in our society, everyone will assume responsibility. Disaster is a phenomenon that has an impact on the whole of society and everyone carries responsibility. This concept must constitute the functional foundation of disaster education. One next research plan is to apply the test we have developed to define the concept of disaster and delineate its scope to different population groups. And in this, we will again be asking, "Is an earthquake an actual disaster?"

\section{References}

American College of Emergency Physicians [ACEP]. (2012, July 19). Disasters. Retrieved fromhttp://www.acep.org/search.aspx?searchtext=disaster

Akdur, R. (2005). Afetlere karşı kurumsal hazırlık afet sürecinde yapılacak işler. In M. Eryılmaz \& U. Dizer (Eds.), . Afet Tibbi (pp. 205-212). Ankara: Ünsal Yayınları.

Alkan, N., Elmas, İ., Karakuş, M. \& Akkay, E. (2001). Doğal afetler sırasında karşılaşılan sorunlar: Bir anket çalışması. Ulusal Travma Dergisi, 7(3), 195-200.

Altıntaş, K. H. (2005). Afet tıbbında eğitim ve öğretim. Hacettepe Tıp Dergisi, 36(3), 139-146.

Arslan, A. (2003). Türkiye'de tabii afetler (1923-1950) (Unpublished master's thesis). Firat Üniversitesi, Elazı ̆̆.

Ault, C. R. (1982). Time in geological explanations as perceived by elementary-school students. Journal of Geological Education, 30(5), 304-309.

Aycan, S., Toprak, İ., Yüksel, B., Özer, H. \& Çakır, B. (2002, December 10). Afet durumlarında beslenme hizmetleri. Retrieved from http://ashgm.saglik.gov.tr/dosya/1-78705/h/a

Aydın, F. (2010). İlköğretim sekizinci sınıf öğrencilerinin “deprem” kavramını algılamaları: Fenomenografik bir analiz. Turkish Studies-International Periodical For the Languages, Literature and History of Turkish or Turkic, 5 (2), 801-817.

Aydın, M. (2012, April 10). Afetlere hazırlık ve afet sonrası müdahale süreçleri. Retrieved from http://www.tid.web.tr/ortak icerik/tid.web/152/4-\%20Mustafa\%20AYDIN.pdf

Barrow, L. \& Haskins, S. (1996). Earthquake knowledge and experiences of introductory geology students. Journal of College Science Teaching, 26(2), 143-146.

Başbuğ-Erkan, B. B., Özmen, B. \& Güler, H. (2011). Türkiye’de afet zarar azaltımını sürdürülebilir eğitimle sağlamak. Proceedings from 1. Türkiye Deprem Mühendisliği ve Sismoloji Konferansl, 2011, October 11-14, Ankara.

Başıbüyük, A. (2004). Yetişkinlerde deprem bilgisi ve etkili faktörlerin incelenmesi. Milli Eğitim Dergisi, 161(1), 215-218.

Battal, F. (2007). Doğal afetlerin yapısal risk yönetimi (Unpublished master's thesis).Çankaya Üniversitesi, Ankara.

Bengtsson, L., Lu, X., Thorson, A., Garfield, R. \& Schreeb, J. (2011). Improved response to disasters and outbreaks by tracking population movements with mobile phone network data: a post-earthquake geospatial study in Haiti. PLoSMed, 8(8), 1-9.

Blake, A. (2005). Do young children's ideas about the Earth's Structure and processes reveal underlying patterns of descriptive and causal understanding in Earth Science. Research in Science and Technological Education, 23(1), 59-74.

Buluş Kırıkkaya, E., Çakın, O., İmalı, B. \& Bozkurt, E. (2011). Earthquake training is gaining importance: the views of 4th and 5th year students on earthquake. Proceedings from: 3rd World Conference on Educational Sciences, 2011, February 3-7, İstanbul.

Buluş Kırıkkaya, E. Oğuz-Ünver, A. \& Çakin, O. (2011). Teachers views on the topic of disaster education at the field on elementary science and technology curriculum. Necatibey Eğitim Fakültesi Elektronik Fen veMatematik Ĕgitimi Dergisi, 5(1), 24-42.

Buluş Kırıkkaya, E. \& İmalı, B. (2013). What are teachers' opinions about including topics of natural events and their risks in primary curriculum in Kocaeli (Turkey)?.Asia-Pacific forum on Science Learning and Teaching, 14(1). 
Cannon, T. (1994). Vulnerability analysis and the explanation of 'natural' disasters. In A. Varley (Ed.). Disasters, Development and Environment.New York: John Wiley\&Sons.

Capelle, W. (2006). Sokrates'ten önce felsefe (O. Özügül, Trans.). İstanbul: Pencere Yayınları.

CassiusDio. (1914). Dio's Roman History (Cassius Dio Cocceianus).. (E., Cary, H. B. Foster, \& W. Heinemann Trans.) . London, New York: Harvard UniversityPress.

Coşkun, Ş. (2011). Afet ĕgitimi algılaması: İlköğretim öğrencilerine verilen afet ĕgitimlerinin algılanmasını ölçmek üzere bir araştırma (Unpublished master's thesis).Sakarya Üniversitesi, Sakarya.

Dal, B. (2009). Öğretmen adaylarının yer bilimleri kavramları hakkındaki düşüncelerinin incelenmesi.Educational Sciences: Theory \& Practice, 9(2), 575-606.

EM-DAT. (2012, May 12). Disasterlist. Retrieved from http://www.emdat.be/disaster-list

Ersoy, Ş. (2013, December 12). 2013 Afet raporu "Dünya ve Türkiye". Retrieved fromhttp://www.yildiz.edu.tr/images/images/2013\%20AFET\%20RA PORU_v2.pdf

Fetihi, L. \& Gülay, H. (2011). The effect of earthquake awareness development program (EADP) on 6 years old children. International Online Journal of Educational Sciences, 3(2), 663-678.

Fuse, A., Igarashi, Y., Tanaka, T., Kim, S., Tsujii, A., Kawai, M. \& Yokota, H. (2011). Onsite medical rounds and fact-finding activities conducted by Nippon Medical School in Miyagi prefecture after the Great East Japan Earthquake 2011. Journal of NipponMedical School, 78(6), 401-404.

Güler, Ç. \& Çobanoğlu, Z. (1994). Afetler. Ankara: Aydoğdu Ofset.

Herodotos. (2006). Tarih (M. Ökmen, Trans.). İstanbul: Türkiye İş Bankası Kültür Yayınları.

Hesiodos. (2000). İşler ve günler tanrıların doğuşu (F.Akderin, Trans.). İstanbul: Say Yayınları.

Higgins, C. M. (2009). Popular and imperial response to earthquakes in The Roman Empire(Unpublished master's thesis). Ohio University, Ohio.

Işık, Ö., Aydınoğlu, H. M., Koç, S., Gündoğdu, O., Korkmaz, G. \& Ay, A. (2012). Afet yönetimi ve afet odaklı sağlık hizmetleri. Okmeydanı Tıp Dergisi, 28(2), 82-123.

Kadığlu, M. (2007). Havadan Sudan. İstanbul: Hayy kitap.

Kadığlu, M. (2011). Afet yönetimi: Beklenilmeyeni beklemek, en kötüsünü yönetmek. İstanbul: T.C. Marmara Belediyeler Birliği yayınları.

Kayrancioğlu, Y. (2007). Türkiye'nin afet yönetim yapısı ve uygulamalar (Unpublished master's thesis). Ankara Üniversitesi, Ankara.

King, C. (2000). The Earth's mantle is solid; Teacher's misconceptions about the Earth and plate tectonics. The School Science Review, 82(3), 57-65.

King, T. A. \& Tarrant, R. A. C. (2013). Children's knowledge, cognitions and emotions surrounding natural disasters: An investigation of year 5 students, Wellington, New Zealand. Australasian Journal of Disaster and Trauma Studies, 2013(1), 17-26.

Koç, H. (2013). Türk basınının doğal afetlere ilişkin bakış açısını belirlemeye yönelik bir inceleme. Journal of World of Turks, 5(2), 121-136.

Leather, A. D. (1987). Views of the natüre and origin of earthquakes and oil held by eleven to seventeen year olds. Geology Teaching, 12(3), 102-108.

Nakajima, Ş. (2012). Deprem ve sonrası psikoloji. Okmeydanı Tıp Dergisi, 28(2), 150-155.

Nakamura, T. (2007, July 15). Disaster risk education at school in Japan. Retrieved fromhttp://drh.edm.bosai.go.jp/Project/Phase2/2Events/9_MiniWS/9 DRH_MiniWS_Nakamura.pdf

Oğuz, A. (2005). Surveying American and Turkish middle school students' existing knowledge of earthquakes by using a systemic network (Unpublished doctoral dissertation). Ohio State University, Ohio.

Oğuz Ünver, A. ve Öztürk, F. (2012). Definition and Scope of Disaster. Proceedings from 9th International Conference on Hands-on Science, Akdeniz Üniversitesi, Antalya.

Öcal, A. (2005). İlköğretim Sosyal Bilgiler dersinde deprem eğitiminin değerlendirilmesi. Gazi Eğitim Fakültesi Dergisi, 25(1), 169-184.

Öcal, A. (2010). İlköğretim aday öğretmenlerinin deprem bilgi düzeyleri üzerine bir araştırma. Mehmet Akif Ersoy Üniversitesi Ĕgitim Fakültesi Dergisi, 8(12), 104-110.

Özgüven, B. (2006). Illkögrretim öğrencilerine verilen temel afet bilinci ĕgitiminin bilgi düzeyine etkisi (Unpublished master's thesis). Dokuz Eylül Üniversitesi, İzmir. 
Pan American Health Organization [PAHO]. (2012, July 19). Retrieved fromhttp://www.paho.org/hq/index.php?option=com content\&view=category\&layout=blog\&id=2394\&I temid=2395\&lang=en

Pallant, J. (2007). SPSS Survival manual, a step by step guide to data analysis using SPSS for Windows. (1st ed.). New York: McGraw-Hill.

Patton, M. Q. (1987). How to use qualitative methods in evaluation. Newbury Park: Sage.

Plinius, Nat. Hist. (Ed. Mayhoff, C. 1892-1909) C. PliniusSecundus. Naturalis Historia (C. Plini Secundi Naturalis Historiae Libri XXXVII. Vols. 1-5, ed.

Ross, K. E. K. \& Dargush, A. (1992). Investigating teacher knowledge of earthquakes. Proceedings from: Tenth World Conference on Earthquake Engineering, 1992, June 19-24, Madrid.

Sever, M. Ş. \& Kazancıoğlu, R. (2012). Van Depremi'nin Ardından: Yine Yeniden Deprem Once More-Still Another Disaster: The Van Earthquake, Türk Nefroloji Diyaliz ve Transplantasyon Dergisi, 21(1), 7-9.

Strabon. (2000). Antik Anadolu Coğrafyası (A. Pekman, Trans.). İstanbul: Arkeoloji ve Sanat Yayınları.

Şahin, S. (2012). Kragos Oros, Titanis Petra ve Patara Apollon Tapınağı Lykia'nın Tarihi Coğrafyası'na İlişkin Bir Lokalizasyon Denemesi. In A.V. Çelgin \& N. E. Akyürek Şahin (Eds.). Eskiçağ yazılar 3 (1-28). İstanbul: Arkeoloji ve Sanat Yayınları.

Şimşek, C. L. (2007). Children's ideas about earthquakes. Journal of Environmental and Science Education, 2(1), 14-19.

Tacitus, annales (1942) Complete Works of Tacitus, (A. J. Church, W. J. Brodribb, \& S. Bryant, Trans.), New York: Random House, Inc. Random House, (Inc. reprinted 1942)

TDK. (2013). Türkçe sözlük. Ankara: Türk Dil Kurumu Yayınları.

Uğurlu, M., Bakım, B., Güveli, M., Karamustafaoğlu, K.O., Soydal, T. \& Ergüder, T. (2003). Afet Yaşantıları, Afet Psikiyatrisi ve Bingöl Depremi Sonrası Ruhsal Müdahale Programı. Düşünen Adam, 16(4), 203210.

Uzunçıbuk, L. (2005). Yerleşim yerlerinde afet ve risk yönetimi (Unpublished master's thesis). Ankara Üniversitesi, Ankara.

Ünalan, Z. (2010). Uyduların gözünden değișen dünya ve doğal afetler. TÜBİTAK Bilim Teknik Dergisi, 514(1), 24-29.

Ünver, G. (2012). Yazıtlar ışı̆̆ında Karia kentlerinde yurttaşların kent imarına katılımları (MÖ 1. - MS 3. yüzyll) (Unpublished doctoral dissertation). Akdeniz Üniversitesi, Antalya.

Varol, N. (2007). Doğal ve teknolojik afetler konusunda toplumun bilinçlendirilmesi ve “AFEM"in rolü. Proceedings from: TMMOB Afet Sempozyumu, Ankara, 127-131.

World Health Organization [WHO]. (2012, April 9). Retrieved from http://search.who.int/search?q=disaster\&ie=utf8\&site=who\&client=_en_r\&proxystylesheet=_en_r\&outp ut=xml_no_dtd\&oe=utf $8 \&$ getfields=doctype

\begin{tabular}{lc}
\hline & Author Information \\
\hline Fulya Ozturk Tasci & Ayse Oguz Unver \\
Privite Turkish School Marmaris KEV Campus & Mugla Sitki Kocman University, Faculty of Education \\
Beldibi-Marmaris/Muğla, Turkey & Kötekli,Menteşe-Muğla, Turkey \\
Contact e-mail: fulya.ozturk@itk.k12.tr & \\
\hline
\end{tabular}

